\title{
Archive and dissemination of marine-earth science data and samples at JAMSTEC
}

March 2014

The Data Research Center (DrC) of JAMSTEC, established in 2009, has handled and disseminated various kinds of data and samples obtained by JAMSTEC as the result of its scientific research. It has been requested to make these valuable data and samples available for educational, societal and economical needs, as well as scientific purposes. Here, we review databases and dissemination systems of these data and samples, which we have developed during the past 5 years of the second midterm plan at the Data Research Center. We also review our recent activities to make our data available for societal needs and discuss some future directions.

Seiji Tsuboi

Deta Research Center for Marine-Earth Sciences Japan Agency for Marine-Earth Science and Technology

\section{海洋研究開発機構に打ける海洋地球観測データの管理と公開に ついて}

2014年3月

地球情報研究センター (DrC)は, 2009年の海洋研究開発機構第2期中期計画開始以来, 海洋研究開発機構 の研究調査船等で取得された様々な海洋地球観測データおよび生物, コアや岩石試料等のサンプルの公開・ 流通を実施してきた。これらのデータ・サンプルについては，科学目的のみならず，様々な社会，教育お よび経済ニーズに即した提供が求められるようになっている。ここでは, DrCが管理公開するデータ・サン プルの現状と，このような新たな利用形態開拓の試みについて解説する.

坪井 誠司

独立行政法人海洋研究開発機構 地球情報研究センター 